\title{
Quality of Work and Quality of Life of Service Sector Workers: Cross-National Variations in Eight European Countries*
}

\author{
Patrick Präg, Maria das Dores Guerreiro, Jouko Nätti, \\ Michael Brookes, and Laura den Dulk
}

2011

\section{Introduction}

How do European service sector workers evaluate their quality of work and life nowadays? Europeanization and globalization are bringing about major shifts in the economy, but we know little about how this is affecting the wellbeing of Europe's citizens. This chapter presents a range of subjective indicators for the quality of work and life as reported by service sector employees in eight European countries. In addition, it provides background information on the organizational context. The countries involved are at different stages of economic development and have differing welfare systems, as explained in Chapter 3 (Kovacheva et al., 2011). Four organizations were surveyed in each country: one bank or insurance company, one public hospital, one retail organization and one IT or telecom company.

This chapter serves as a context for the other chapters in this book. Its aim is to describe and compare subjective indicators of quality of work and life across countries and organizational contexts. Those indicators are: work engagement, stress, work-home interference and enrichment, satisfaction with work-life balance, and overall life satisfaction. The key question addressed by this chapter is: how do these subjective indicators of quality of work and life differ between countries and service sector organizations, and how are they similar? We begin by describing the organizations included in the study, including

*This study was published in 2011 as Chapter 5, "Quality of Work and Quality of Life of Service Sector Workers. Cross-National Variations in Eight European Countries" (pp. 77-94) of Quality of Work and Life. Theory, Practice, and Policy, edited by Margareta BäckWiklund, Tanja van der Lippe, Laura den Dulk, and Anneke van Doorne-Huiskes. Palgrave Macmillan. doi: 10.1057/9780230299443_5. 
workforce characteristics and organizational changes at the time of our research. We have grouped them by sector; in other words, we first discuss the hospitals in the eight countries, followed by the banks/insurance companies, the IT/telecom companies and finally the retail companies. Next, we look at how service sector workers in these organizations and countries evaluate their quality of work and life. Finally, we conclude the chapter with a discussion of our exploration.

\section{Portraits of the service organizations in eight European countries}

\subsection{Public hospitals}

The hospitals participating in this study represent the public sector. Some of the hospitals selected are university hospitals, while others are public hospitals in major cities. In general, the health care sector is dominated by female employees, and this is reflected in the high proportion of female workers in our hospital samples, ranging from 89 per cent in the Finnish hospital to 71 per cent in the UK and Portuguese hospitals. Regarding age, the hospitals in our study have more mature or older workforces than the other service organizations studied, with the average age varying from 39.1 years in the Portuguese hospital to 44.5 years in the Swedish hospital (see Table 1). Compared to other sectors, health care has a relatively highly educated workforce (European Foundation for the Improvement of Living and Working Conditions, 2008). The hospital workers in our study are also often highly educated, the two exceptions being the Dutch and German samples, where the shares of higher educated workers are relatively small. In the Dutch sample, this is because doctors are not included in the sample, as they are not employed by the hospital but are self-employed. The health care sector is considered a relatively favorable one in terms of working conditions, especially with respect to working hours. Compared to other sectors, however, health care workers and social workers are more likely to experience violence at work (Jettinghoff and Houtman, 2009). Organizational change was common among the hospitals in the study. All European countries face growing health care expenses owing to the aging of the population, and at the time of the study many hospitals reported that they were facing financial cuts and reforms. Not all of the hospitals in our study had a recent reduction in their workforce, however; the Finnish and Dutch hospitals, for example, reported a staff increase, and the workforce in the Swedish and German hospitals had remained stable in recent years. 


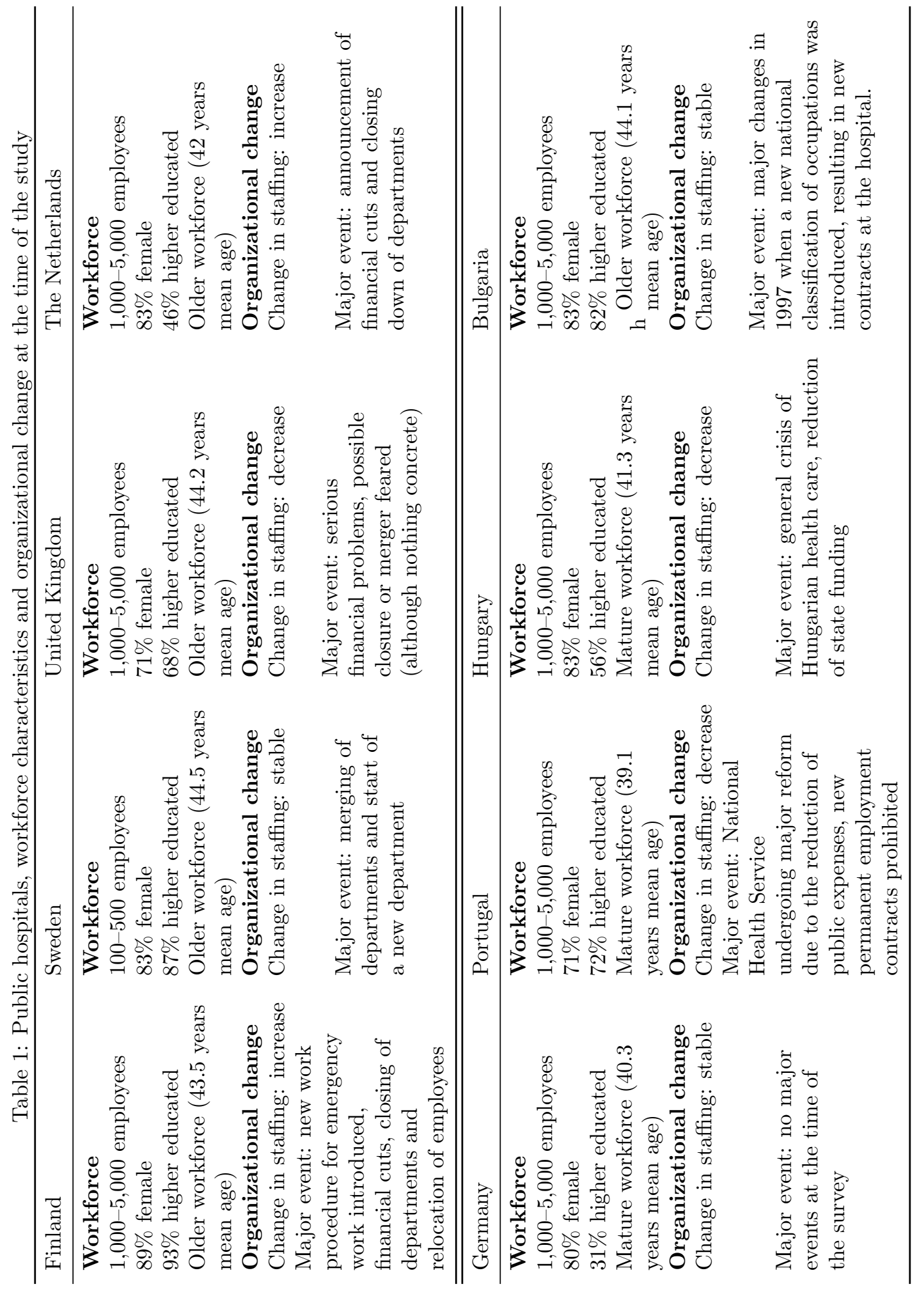




\subsection{Banks and insurance companies}

Based on the European Working Conditions Survey (EWCS), Jettinghoff and Houtman (2009) show that in general, financial sector workers reported relatively favorable physical working conditions, few non-standard hours, highskilled work, and high levels of social support, at least until 2005. Trends in working conditions and job satisfaction show that ambient conditions (such as exposure to noise, fumes, powder, or dust), weekend work, and violence and discrimination decreased in the financial sector, and satisfaction with working conditions increased between 1995 and 2005. As the economic crisis has shown, however, conditions can change rapidly and it is important to note the organizational changes that were taking place at the time of the study. Mergers, takeovers and changes of ownership were very common within the banking and insurance industry, perhaps increasing feelings of job insecurity, in this case meaning uncertainty not about redundancy but about one's future job content or work location. Nevertheless, at the time of the study, our companies still had relatively favorable working conditions. Both banks and insurance companies are included in our study. These are all relatively large organizations, except for the two Scandinavian cases. They have relatively highly educated workforces and a large proportion of female employees. The average age varies between 30.7 years (Germany) and 44.2 years in Finland (see Table 2).

\subsection{IT and telecom companies}

Workers in the telecommunication industry are required to meet heavy demands, that is they often need to work hard and at a breakneck pace (Jettinghoff and Houtman, 2009). Four of the eight companies in our study had faced cuts in staff in the past few years, while the other four reported an increase. IT and telecom companies have a relatively young workforce, with the lowest mean age being found in Bulgaria (32.8 years). The Swedish and German IT companies were exceptions with older workforces (43.8 and 43.9 years, respectively) (see Table 3).

\subsection{Retail companies}

The retail companies were included in the study because they employ a relatively large share of lower educated workers. At first, the aim was to include supermarket chains in every country. Obtaining access to the chains proved difficult, however, and so we extended our focus to other types of retail chains, such as electronics and travel/outdoor shops. Many of the companies included in the study employ a young, largely female workforce, although the British and German shops had older workforces with an average age of 48.7 years. Some of the companies were expanding at the time of the study, whereas others had 


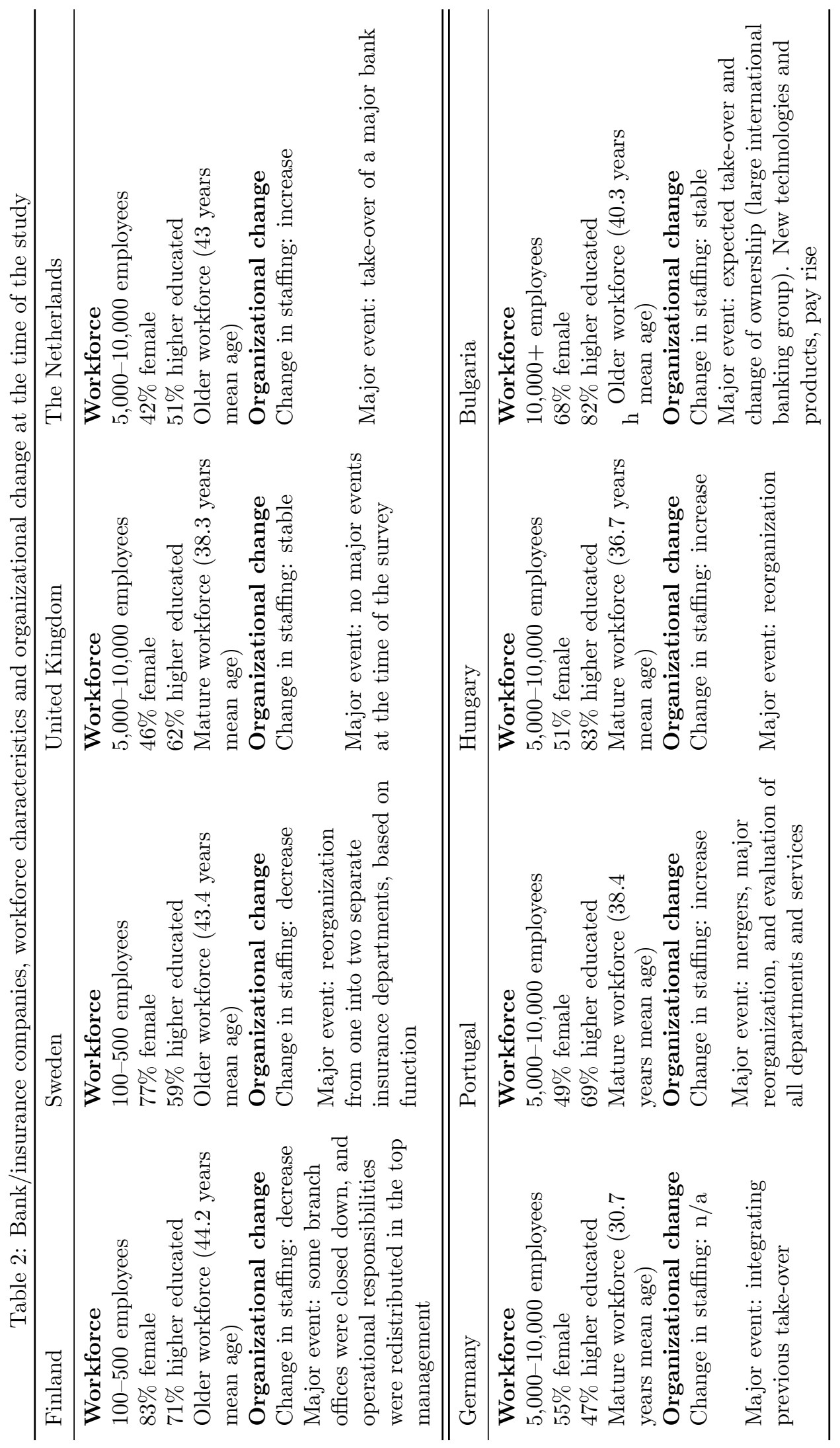




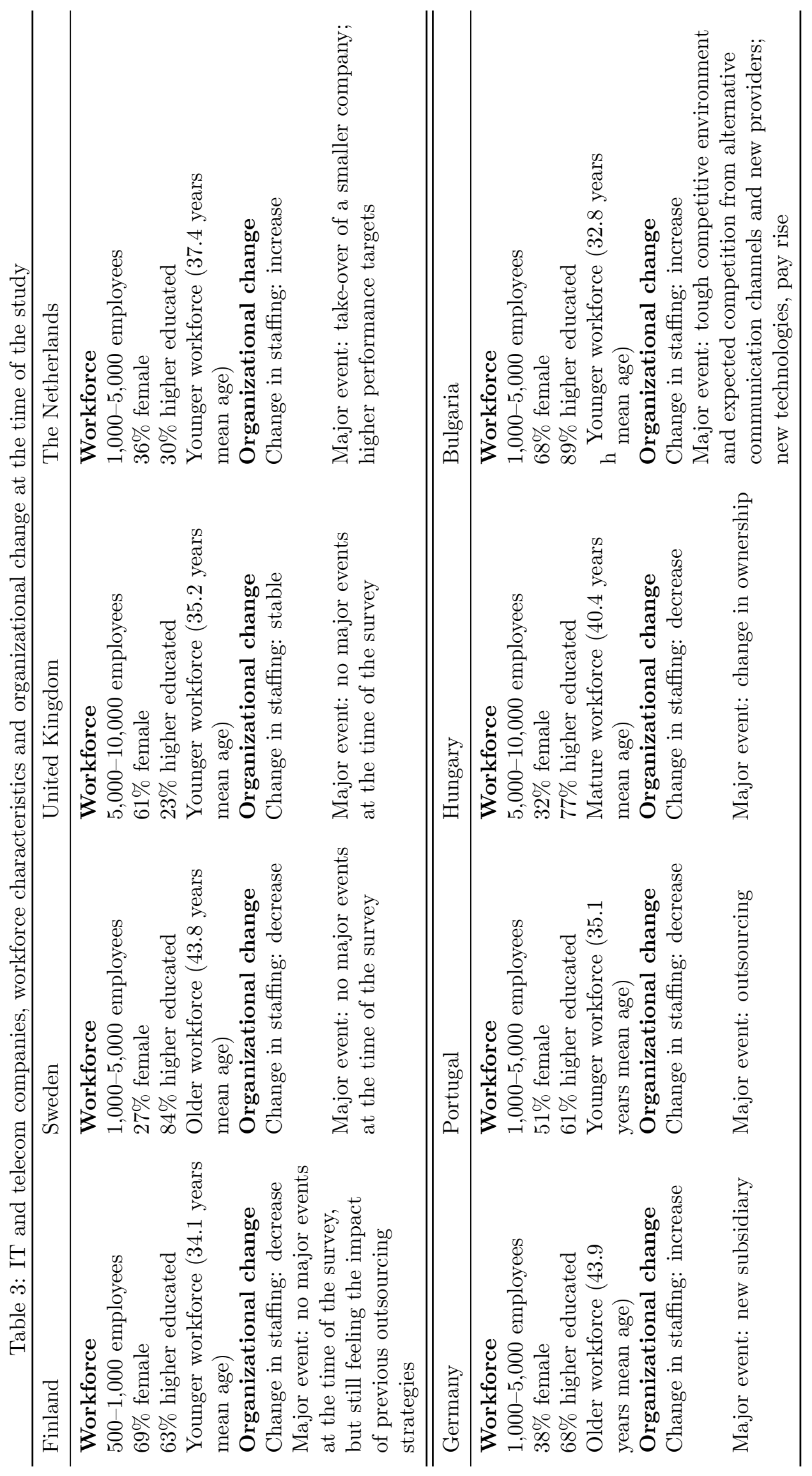


more or less stable workforces. The Dutch case represented a relatively secure work environment because the chain is part of a semi-profit organization (see Table 4).

\subsection{Summary}

The hospitals in our study are fairly similar across the eight countries; they all have a mature or older, female, professional workforce and they are all facing financial cuts and reforms, although some of these are more drastic than others. The banks and insurance companies also have an older and highly educated workforce. The banking and insurance industry offers relatively good working conditions in most countries, but employees are also experiencing considerable turbulence and change. Many telecom companies in this study have a young workforce, and they differ considerably from one another when it comes to staffing: some are increasing staff and some are downsizing their workforce. They operate in a highly competitive market, and outsourcing, mergers and takeovers are common. The retail companies have a lower educated, largely female workforce than the other service organizations and are also subject to much turbulence and change; some are doing better than others. Hence, despite our including comparable cases, there are some striking organizational differences between countries within the four sectors.

\section{Subjective indicators of quality of work and life}

We have seen that the 32 organizations vary considerably in their demographic composition both within countries and industries. In order to obtain comparable estimates of cross-national variation in the quality of life, we present adjusted means derived from analyses of covariance (ANCOVA, Keppel and Wickens, 2004). The adjusted means show country and organizational averages in the quality of life and work net of differences in age, percentage of female workers, educational attainment and sample size. In other words, these are the means that we would expect to find if the demographic make-up (in terms of age, gender and education) of all the organizations was equal to the empirical average found across countries and industries. In addition, all indicators presented below have been converted from the original scale to a range of 0 to 100. Reported values thus represent the percentage of the maximum value that could have been measured. This conversion makes it easier to interpret the indicators (Cohen et al., 1999) and is frequently used in some areas of quality of life research (e.g. Cummins, 2003). In this section, we first compare perceived quality of life and work across coun-tries. We then consider the variation between sectors within 


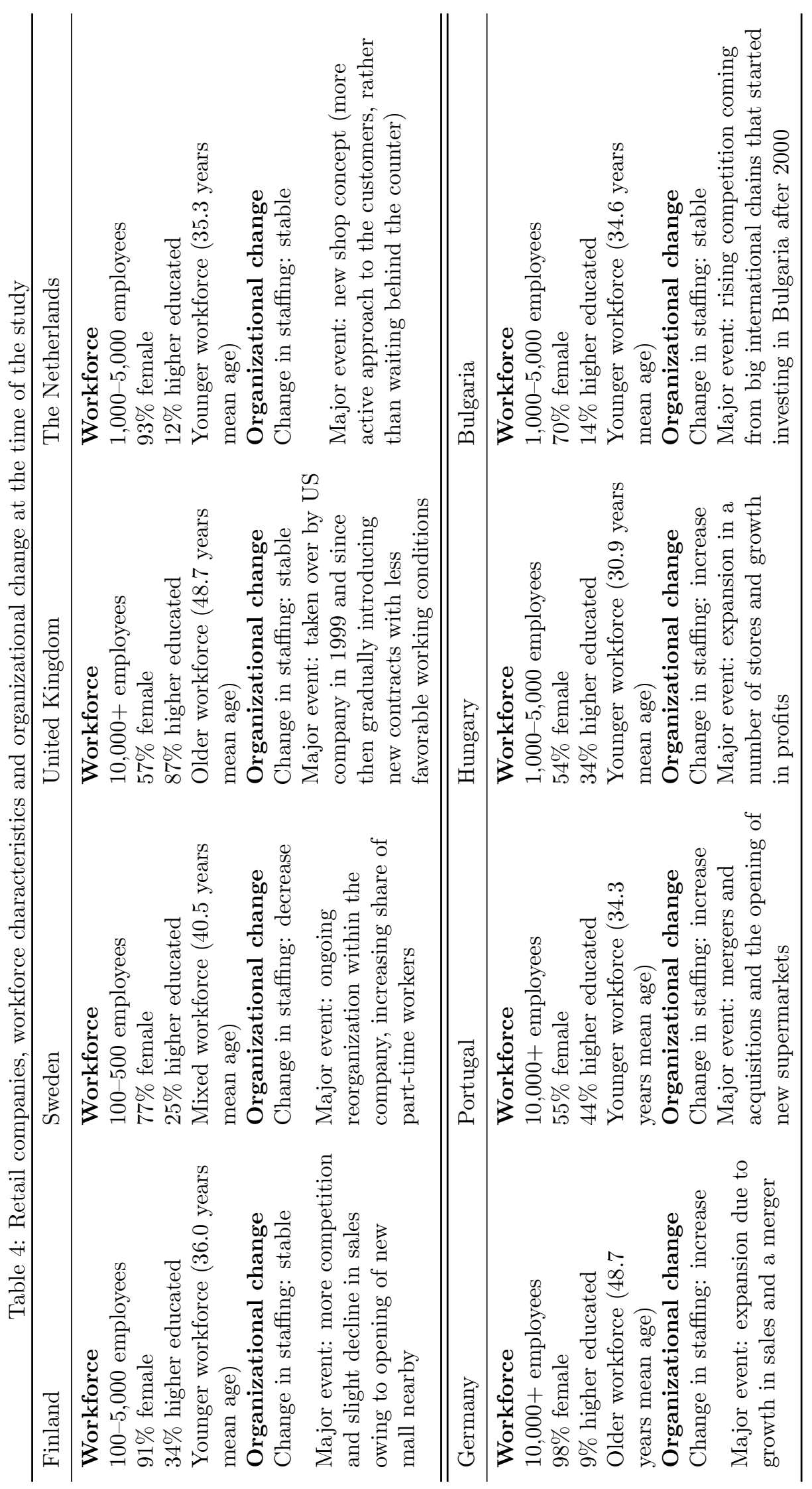


countries and possible patterns according to type of sector.

\subsection{Quality of work and life across countries}

\subsubsection{Work engagement}

How happy are employees at work? Work engagement expresses how good people feel at work. Work engagement is typified by vigor, dedication and absorption (Schaufeli et al., 2002). It is based on the concept of 'flow,' which has its origins in positive psychology (Seligman and Csikszentmihalyi, 2000). In order to measure work engagement, we used seven items taken from the Utrecht Work Engagement Scale (Schaufeli et al., 2006; van der Lippe et al., 2011).

Research has shown that work engagement is related to job resources such as working time and work intensity, job autonomy, training and relationships with colleagues (Lewis et al., 2009). Results obtained in this survey rank The Netherlands (71 per cent) as having the highest levels of work engagement and the United Kingdom as having the lowest (53 per cent). Portugal (69 per cent), Sweden (66 per cent), Hungary (66 per cent), Bulgaria (63 per cent) and Germany and Finland (61 per cent both) are ranked between these two extremes (Panel (a) of Figure 1).

\subsubsection{Stress}

Stress is a common phenomenon in contemporary life and represents an individual's response to the demands of his or her environment (Weinberg and Cooper, 2007). Much of the research on the quality of working life focuses on occupational stress, burnout, work-family conflict and other negative outcomes. Stress may be caused by heavy job demands and a lack of job resources, as well as demands associated with other life domains such as the family (see den Dulk et al., 2011). In this sample, average job-related stress across the eight countries is greater than private or family-related stress.

Panel (b) of Figure 1 shows that workplace stress affects about half of the respondents, with the largest percentages being in the United Kingdom (50 per cent), Portugal (47 per cent) and Hungary (46 per cent). These are all countries where employees work long hours. The lowest percentages were found in The Netherlands (33 per cent) and Bulgaria (36 per cent), despite differences in the average number of hours worked in the two countries. Finland, Sweden and Germany are in the middle bracket.

Family-related stress is less common among our service sector workers. In the United Kingdom, 37 per cent and in Portugal 35 per cent of workers report family-related stress. The Nordic countries are ranked in the middle, together with Germany and Hungary. Bulgaria and The Netherlands have the lowest levels of family-related stress at 25 and 27 per cent respectively. 


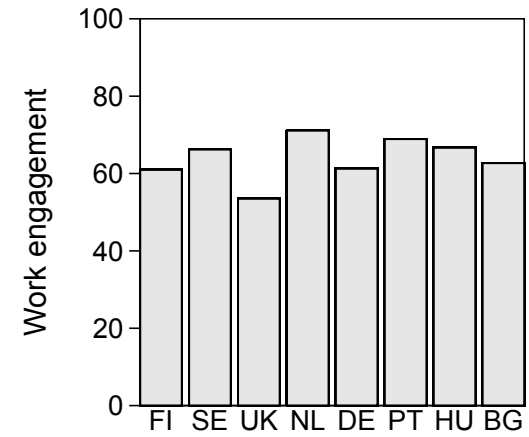

(a) Work engagement

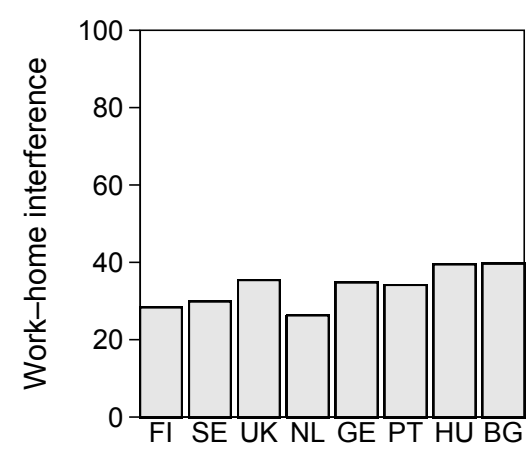

(c) Work-home interference

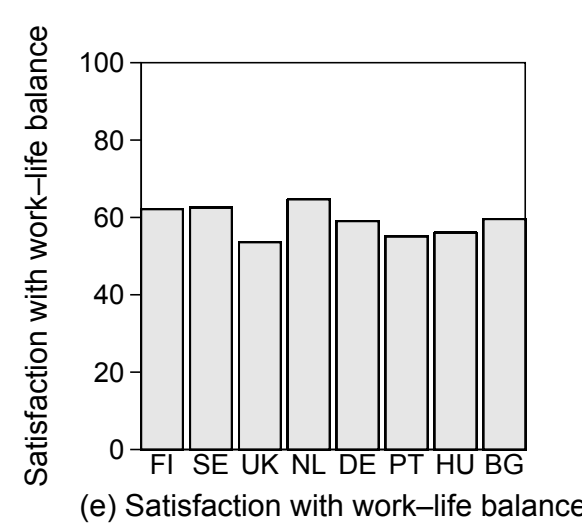

(e) Satisfaction with work-life balance

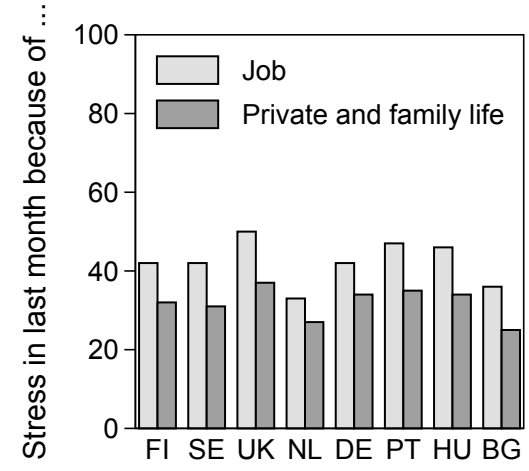

(b) Stress

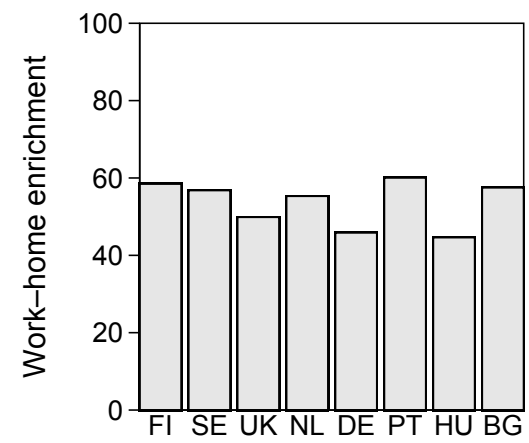

(d) Work-home enrichment

Figure 1: Subjective measures of quality of work (adjusted means) 


\subsubsection{Work-home interference and enrichment}

Increasingly, employees combine paid work with other life activities. The worklife balance has hence become an important dimension of the quality of work and life. The literature shows that combining paid work with other life domains may have a positive as well as a negative impact on quality of life (see den Dulk et al., 2011). Den Dulk et al. (2011) argue that a lack of resources and heavy work and/or household demands can result in negative work-to-home or home-to-work interference or conflict. From a positive perspective, work-home enrichment refers to the extent to which experiences in one domain improve the quality of life in the other (Carlson et al., 2006; Greenhaus and Powell, 2006). Panel (c) of Figure 1 shows the average work-to-home interference experienced by European service sector workers, as measured by three items on a scale developed by Geurts et al. (2005).

It turns out that around 40 per cent of Bulgarian and Hungarian service sector employees report work-to-home interference. In the United Kingdom and Germany, this is 35 per cent, and in Portugal 34 per cent. Workers reporting the least amount of work-home interference were found in Sweden (30 per cent), Finland (28 per cent) and The Netherlands (26 per cent).

A growing number of researchers have been exploring the positive aspects of combining work and family life in recent years. As some authors have argued, professional activity can have a positive effect on the private domain. Moen et al. (1992), for instance, were able to show that women's multiple-role involvement had long-term positive effects on their health and social integration. Work can benefit the family regardless of the amount of perceived difficulty balancing home and work. The beneficial aspects of multiple-role engagement have gained in relevance (Grzywacz and Butler, 2005; Voydanoff, 2005; Greenhaus and Powell, 2006). Work is beneficial not only because it gives families resources and satisfies their material needs in the form of pay, but also because the social and interpersonal relationships established in the workplace produce social capital. It is at work that people make friends and acquaintances, build networks, and get the information and support they need to resolve problems in the domestic domain. This is especially true when people curtail their social lives outside of work because they have so little time left after working long hours. In order to assess to what extent European service sector workers believe their jobs enrich their private lives, we used a measure consisting of three items taken from the work-family enrichment scale developed by Carlson et al. (2006).

Panel (d) of Figure 1 reveals some variation across countries. Basically, we can distinguish two groups of countries with relatively high and relatively low levels of work-to-home enrichment. On average, service sector workers in Portugal (60), Bulgaria (58), Finland (58), Sweden (57), and The Netherlands 
(55) find their jobs enriching for their private lives. Employees in Germany (46) and Hungary (45) generally perceive less work-to-home enrichment, while British service sector workers award a mean score of 50 .

\subsubsection{Satisfaction with work-life balance}

Another way of conceptualizing the way work and home impact on quality of life is the notion of work-life balance satisfaction (Eby et al., 2005; Poelmans et al., 2005). This concept, developed by Valcour (2007), is defined as 'an overall level of contentment resulting from an assessment of one's degree of success at meeting work and family role demands' (Valcour, 2007, p. 1512, see also van der Lippe et al. (2011)). A perceived conflict between work and family is negatively related to life satisfaction, job satisfaction, and organizational commitment (Kossek and Ozeki, 1998; Allen et al., 2000), and positively related to health problems (Grzywacz and Tucker, 2008). A number of authors stipulate that workers in the Nordic countries should be experiencing the highest levels of work-life balance satisfaction owing to the family support policies of the social-democratic welfare regimes (Crompton and Lyonette, 2006; Leitner and Wroblewski, 2006). However, other researchers show that women in the Nordic countries are actually less satisfied with their ability to combine work and family (Scherer and Steiber, 2007). This is related to the large proportion of women who work full time in Sweden and Finland, a pattern that is in fact stimulated by generous work-family policies. After returning to work from what are indeed long and generous parental leaves, women tend to combine childcare responsibilities with full-time jobs, potentially leading to work-home interference. In addition, Drobnič et al. (2010) show that although work-life interference is more serious in the less affluent European countries than in the richer Nordic and Western European countries, it is only workers in the latter countries who perceive their life satisfaction as being negatively affected by work-life interference. In order to assess European workers' satisfaction with their ability to combine work and private life, we used a three-item measure developed by Valcour (2007).

Panel (e) of Figure 1 shows service sector workers' average satisfaction with their work-life balance. Country differences are fairly small but significant. Dutch employees, a large percentage of whom work part time, express the largest degree of satisfaction with their work-life balance, reaching a score of 65 . On average, Swedish and Finnish service sector workers have slightly lower scores (62). Bulgarians assign a mean score of 60 , followed by Germans (59), Hungarians (56), Portuguese (55), and British (54) workers. Respondents in these countries also report the least amount of support from their superiors, notably when they want to reduce their working hours for personal reasons. Bulgarians, Hungarians, and the Portuguese also report a higher average number of work- 


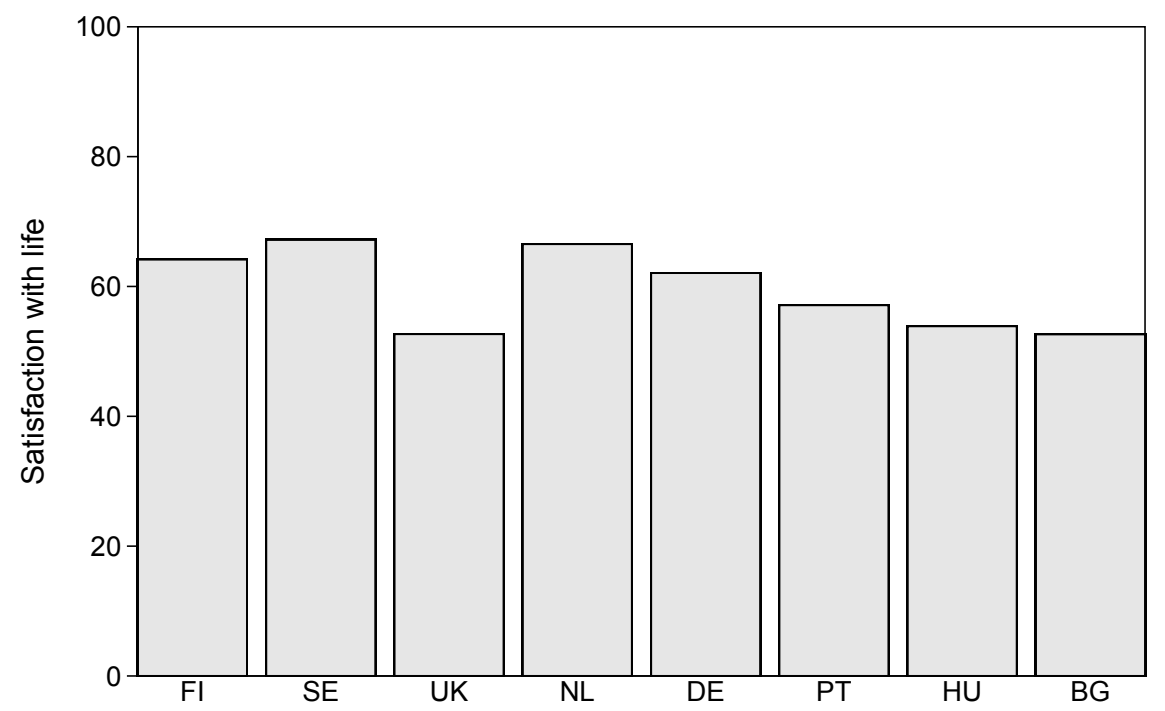

Figure 2: Overall life satisfaction by country (adjusted means)

ing hours; in these countries, the long-hours culture tends to prevail (Burke and Cooper, 2008).

\subsection{Overall life satisfaction}

The final subjective measure of quality of life is overall life satisfaction, which we measured using the well-established scale developed by Pavot and Diener (1993). Life satisfaction is defined as an individual's subjective judgment of their overall quality of life, based on their own set of criteria: 'The quality of life must be in the eye of the beholder' (Campbell, 1972, p. 442). As a measure of subjective wellbeing, this judgment is considered the cognitive component, as opposed to the affective component, which in turn comprises pleasant and unpleasant affects. There is consensus among quality of life researchers that subjective and objective measures should be considered together (Präg et al., 2010).

In empirical terms, Figure 2 shows us that there is a marked divide in overall life satisfaction between the countries under study. The highest level of overall life satisfaction has been observed among Swedish and Dutch service sector workers. Both have average scores of roughly 67 on the satisfaction with life scale. Finland and Germany are close behind, with scores of 64 and 62, respectively. Life satisfaction for service sector workers in the other countries is considerably lower. On average, Portuguese workers score 57, Hungarians have a mean of 54 and both British and Bulgarian workers score approximately 
53 on the satisfaction with life scale. These results are roughly in line with findings from representative cross-national studies (e.g. Drobnič et al., 2010). Cross-national differences in life satisfaction are often attributed to economic development and national wealth (Diener and Suh, 1999; Fahey and Smyth, 2004). However, the fact that British workers score at the same level as Bulgarian workers strongly suggests that there are also other mechanisms at play. Findings from other studies generally confirm that life and job satisfaction levels are lower and work-home interference levels higher in the UK than in Sweden, Finland, The Netherlands, and Germany (Fahey and Smyth, 2004; Pichler and Wallace, 2009). In general, however, the difference between UK scores and those in other Western European countries tends to be smaller than observed in our study of service sector workers (see also Szücs et al., 2011).

Research on the quality of life contends that overall life satisfaction is located at the very top of a domain hierarchy that organizes individuals' memories and perceptions within these domains (Sirgy, 2002). Material wellbeing and social relationships are two very important life domains relating to overall life satisfaction. There is a considerable amount of research literature on the effects of material conditions (Clark et al., 2008; Diener et al., 1993; Diener and BiswasDiener, 2002; Easterlin, 2001) suggesting that the correlation between income and life satisfaction is moderate, and that increases in income generate little if any additional satisfaction once a certain level of income has been reached. There is evidence, however, that differences in life satisfaction are considerable between the rich and the poor (Lucas and Schimmack, 2009) and that income plays a more important role in less affluent countries (Drobnič et al., 2010). This sample of service sector workers combines better paying and more prestigious occupations, for instance in health care (e.g. doctors), and more precarious and poorly paid occupations (e.g. the majority of retail jobs). Socio-economic wellbeing, measured here as a worker's level of satisfaction with his or her household income, is a salient predictor for overall wellbeing (van Praag et al., 2003).

\section{Comparing organizations across countries}

Besides differences between countries with respect to quality of life, the data have also revealed variations between organizations. Figure 3 illustrates this for the indicator overall life satisfaction. Earlier in this chapter, we saw notable differences between countries in overall life satisfaction. If we take the employing organization into account, we also see variation across organizations within countries.

The highest level of overall life satisfaction can be found among Finnish bank workers, but it is not the case that bank/insurance employees report the highest levels of life satisfaction in every country in our survey. For example, in The 


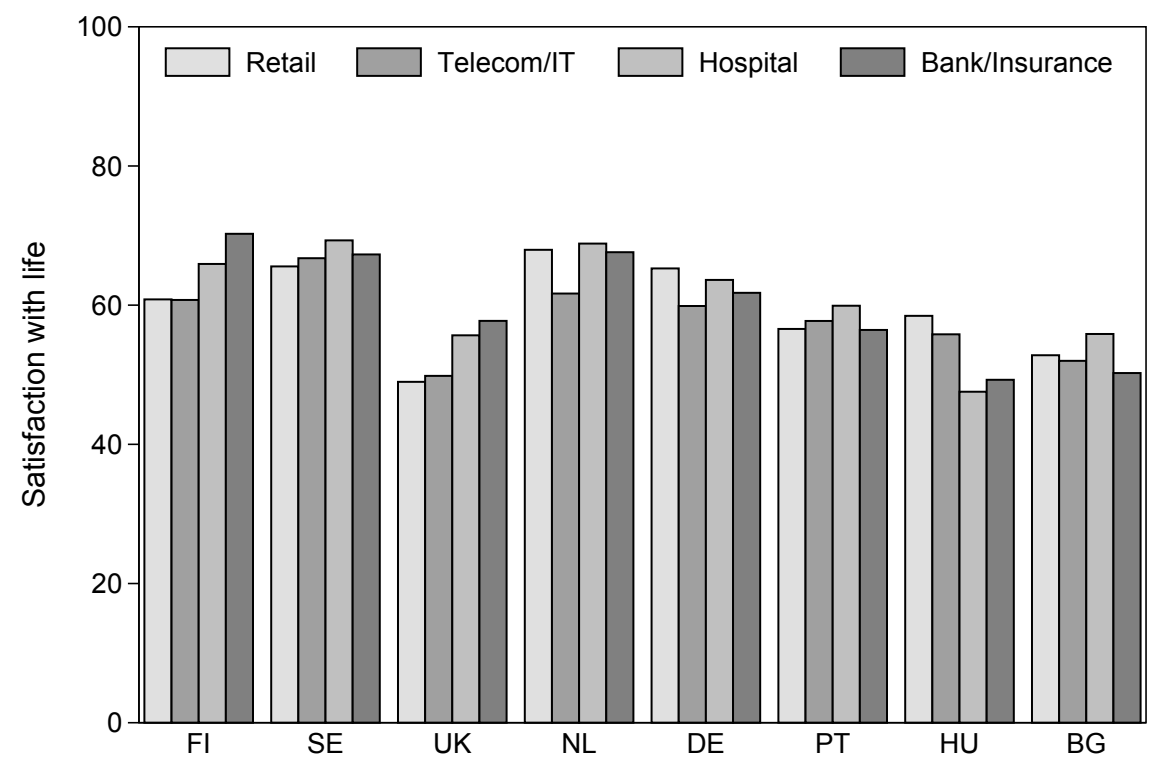

Figure 3: Overall life satisfaction by organization

Netherlands and Bulgaria it is hospital workers who score highest (although at a far lower level in the latter country), while in Hungary, hospital workers and bank employees in fact have the lowest scores. In many countries (although not in all), telecom workers are generally the least satisfied with their lives. In other words, we see no clear pattern by organization within our data set, unlike the country differences. This is also true for the other subjective quality of work and life indicators.

\section{Discussion}

At a time of enormous change in the world economy, socially sustain-able working conditions that preserve and improve the quality of life are a crucial issue in Europe. Drawing on a survey conducted in 32 service sector organizations in eight European countries, this chapter presented the cross-national distribution of subjective quality of life indicators of service sector workers, including work engagement, stress, work-home interference and enrichment, satisfaction with work-life balance, and overall life satisfaction. Although we cannot assume that our samples are representative, we can report a number of interesting outcomes.

For most indicators, Swedish, Finnish and Dutch employees reported similarly high levels of contentment, namely overall life satisfaction, work-life balance satisfaction, and work engagement. A gloomier image of quality of life and work emerges for the less affluent countries, Portugal, Hungary, and Bulgaria. 
Service sector workers from these countries score among the lowest on most indicators. Only for work-to-home enrichment do Portuguese and Bulgarian employees rank highest.

Remarkably, British service sector workers have scores similar to those of employees from less affluent countries when it comes to quality of work and life. On both work and non-work indicators, their scores are comparable and often lower. German service sector workers range in between these two groups.

The aim of this chapter was to explore the data with a view to the subjective indicators of quality of life. The key question was: what are the differences and similarities in quality of life between countries and across service sector organizations? We found a consistent pattern of country-specific differences, as discussed above, but organizational differences were less clear. The description of the various organizational contexts revealed major variations in workforce characteristics, but even sharper differences in terms of organizational change and economic position (increase or decrease in staff numbers). The differences between organizations in similar sectors show that there is no clear pattern across organizations when it comes to the subjective indicators of quality of work and life. Subsequent chapters, which focus more on explanatory analysis, may shed more light on the role of the organizational context.

\section{References}

Allen, Tammy D., David E. L. Herst, Carly S. Bruck, and Martha Sutton, 2000. 'Consequences Associated with Work-to-Family Conflict. A Review and Agenda for Future Research.' Journal of Occupational Health Psychology 5(2): 278-308. doi: 10.1037/1076-8998.5.2.278.

Burke, Ronald J. and Cary L. Cooper, 2008. The Long Work Hours Culture. Causes, Consequences, and Choices. Bingley: Emerald.

Campbell, Angus, 1972. 'Aspiration, Satisfaction, and Fulfillment.' In Campbell, Angus and Philip Converse, eds., The Human Meaning of Social Change, pp. 441-446. New York: Russell Sage.

Carlson, Dawn S., K. Michele Kacmar, Julie Holliday Wayne, and Joseph G. Grzywacz, 2006. 'Measuring the Positive Side of the Work-Family Interface. Development and Validation of a Work-Family Enrichment Scale.' Journal of Vocational Behavior 68(1): 131-164. doi: 10.1016/j.jvb.2005.02.002.

Clark, Andrew E., Paul Frijters, and Michael A. Shields, 2008. 'Relative Income, Happiness, and Utility. An Explanation for the Easterlin Paradox and Other Puzzles.' Journal of Economic Literature 46(1): 95-144. doi: 10.1257/jel.46.1.95. 
Cohen, Patricia, Jacob Cohen, Leona S. Aiken, and Stephen G. West, 1999. 'The Problem of Units and the Circumstance for POMP.' Multivariate Behavioral Research 34(3): 315-346. doi: 10.1207/S15327906MBR3403_2.

Crompton, Rosemary and Clare Lyonette, 2006. 'Work-Life 'Balance' in Europe.' Acta Sociologica 49(4): 379-393. doi: 10.1177/0001699306071680.

Cummins, Robert A., 2003. 'Normative Life Satisfaction. Measurement Issues and a Homeostatic Model.' Social Indicators Research 64(2): 225-256. doi: 10.1023/A:1024712527648.

den Dulk, Laura, Margareta Bäck-Wiklund, Suzan Lewis, and Dorottya Redai, 2011. 'Quality of Life and Work in a Changing Europe. A Theoretical Framework.' In Bäck-Wiklund, Margareta, Tanja van der Lippe, Laura den Dulk, and Anneke Doorne-Huiskes, eds., Quality of Life and Work in Europe. Theory, Practice, and Policy, pp. 17-31. Houndsmills, Basingstoke: Palgrave Macmillan. doi: 10.1057/9780230299443_2.

Diener, Ed and Robert Biswas-Diener, 2002. 'Will Money Increase Subjective Wellbeing? A Literature Review and Guide to Needed Research.' Social Indicators Research 57(2): 119-169. doi: 10.1023/A:1014411319119.

Diener, Ed, Ed Sandvik, Larry Seidlitz, and Marissa Diener, 1993. 'The Relationship between Income and Subjective Wellbeing. Relative or Absolute?' Social Indicators Research 28(3): 195-223. doi: 10.1007/BF01079018.

Diener, Ed and Mark Eunkook Suh, 1999. 'National Differences in Subjective Well-Being.' In Kahneman, Daniel, Ed Diener, and Norbert Schwarz, eds., Well-Being. The Foundations of Hedonic Psychology, pp. 434-450. New York: Russell Sage.

Drobnič, Sonja, Barbara Beham, and Patrick Präg, 2010. 'Good Job, Good Life? Working Conditions and Quality of Life in Europe.' Social Indicators Research 99(2): 205-225. doi: 10.1007/s11205-010-9586-7.

Easterlin, Richard A., 2001. 'Income and Happiness. Towards a Unified Theory.' Economic Journal 111(473): 465-484. doi: 10.1111/1468-0297.00646.

Eby, Lillian T., Wendy J. Casper, Angie Lockwood, Chris Bordeaux, and Andi Brinley, 2005. 'Work and Family Research in IO/OB. Content Analysis and Review of the Literature (1980-2002).' Journal of Vocational Behavior 66(1): 124-197. doi: 10.1016/j.jvb.2003.11.003.

European Foundation for the Improvement of Living and Working Conditions, 2008. Health and Social Work Fact Sheet. Dublin: Eurofound. 
Fahey, Tony and Emer Smyth, 2004. 'Do Subjective Indicators Measure Welfare? Evidence from 33 European Societies.' European Societies 6(1): 5-27. doi: $10.1080 / 1461669032000176297$.

Geurts, Sabine A. E., Toon W. Taris, Michiel A. J. Kompier, Josje S. E. Dikkers, Madelon L. M. Van Hooff, and Ulla M. Kinnunen, 2005. 'WorkHome Interaction from a Work Psychological Perspective. Development and Validation of a New Questionnaire, the SWING.' Work and Stress. An International Journal of Work, Health, and Organisations 19(4): 319-339. doi: $10.1080 / 02678370500410208$.

Greenhaus, Jeffrey H. and Gary N. Powell, 2006. 'When Work and Family are Allies. A Theory of Work-Family Enrichment.' Academy of Management Review 31(1): 72-92. doi: 10.5465/AMR.2006.19379625.

Grzywacz, Joseph G. and Adam B. Butler, 2005. 'The Impact of Job Characteristics on Work-to-Family Facilitation. Testing a Theory and Distinguishing a Construct.' Journal of Occupational Health Psychology 10(2): 97-109. doi: 10.1037/1076-8998.10.2.97.

Grzywacz, Joseph G. and Jenna Tucker, 2008. 'Work-Family Experiences and Physical Health. A Summary and Critical Review.' In Kossek, Ellen and Marcie Pitt-Catsouphes, eds., Work and Family Encyclopedia. Chestnut Hill, MA: Sloan Work and Family Research Network.

Jettinghoff, Karin and Irene Houtman, 2009. A Sector Perspective on Working Conditions. Dublin: Eurofound.

Keppel, Geoffrey and Thomas D. Wickens, 2004. Design and Analysis. A Researcher's Handbook. Upper Saddle River, NJ: Pearson/Prentice-Hall, 4th edition.

Kossek, Ellen Ernst and Cynthia Ozeki, 1998. 'Work-Family Conflict, Policies, and the Job-Life Satisfaction Relationship. A Review and Directions for Organizational Behavior-Human Resources Research.' Journal of Applied Psychology 83(2): 139-149. doi: 10.1037/0021-9010.83.2.139.

Kovacheva, Siyka, Anneke Van Doorne-Huiskes, and Timo Anttila, 2011. 'The Institutional Context of the Quality of Life.' In Bäck-Wiklund, Margareta, Tanja Van der Lippe, Laura Den Dulk, and Anneke Van DoorneHuiskes, eds., Quality of Life and Work in Europe. Theory, Practice, and Policy, pp. 32-54. Houndsmills, Basingstoke: Palgrave Macmillan. doi: 10.1057/9780230299443_3.

Leitner, Andrea and Angela Wroblewski, 2006. 'Welfare States and Work-Life Balance. Can Good Practices Be Transferred from the Nordic Countries 
to Conservative Welfare States?' European Societies 8(2): 295-317. doi: $10.1080 / 14616690600645092$.

Lewis, Suzan, Maria das Dores Horta Guerreiro, Michael Brookes, Eduardo Alexandre Anastácio Rodriguez, and Ana Margarida Martins Barroso, 2009. Work Engagement, Work-Family Enrichment, and Gender in Portugal and the UK. Lisbon: 9th European Sociological Association Conference, September $2-5$.

Lucas, Richard E. and Ulrich Schimmack, 2009. 'Income and Wellbeing. How Big Is the Gap between the Rich and the Poor?' Journal of Research in Personality 43(1): 75-78. doi: 10.1016/j.jrp.2008.09.004.

Moen, Phyllis, Donna Dempster-McClain, and Jr. Williams, Robin M., 1992. 'Successful Aging. A Life-Course Perspective on Women's Multiple Roles and Health.' American Journal of Sociology 97(6): 1612-1638. doi: $10.1086 / 229941$.

Pavot, William and Ed Diener, 1993. 'Review of the Satisfaction with Life Scale.' Psychological Assessment 5(2): 164-172. doi: 10.1037/1040-3590.5.2.164.

Pichler, Florian and Claire Wallace, 2009. 'What are the Reasons for Differences in Job Satisfaction across Europe? Individual, Compositional, and Institutional Explanations.' European Sociological Review 25(5): 535-549. doi: $10.1093 /$ esr/jcn070.

Poelmans, Steven A. Y., Michael O’Driscoll, and Barbara Beham, 2005. 'An Overview of International Research on the Work-Family Interface.' In Poelmans, Steven A. Y., ed., Work and Family. An International Research Perspective, pp. 3-46. Mahwah, NJ: Erlbaum. doi: 10.4324/9781410612601.

Präg, Patrick, Steffen Mau, and Roland Verwiebe, 2010. 'Quality of Life.' In Mau, Steffen and Roland Verwiebe, eds., European Societies. Mapping Structure and Change, pp. 225-260. Bristol: Policy.

Schaufeli, Wilmar B., Arnold B. Bakker, and Marisa Salanova, 2006. 'The Measurement of Work Engagement With a Short Questionnaire. A CrossNational Study.' Educational and Psychological Measurement 66(4): 701-716. doi: $10.1177 / 0013164405282471$.

Schaufeli, Wilmar B., Marisa Salanova, Vicente González-romá, and Arnold B. Bakker, 2002. 'The Measurement of Engagement and Burnout. A Two Sample Confirmatory Factor Analytic Approach.' Journal of Happiness Studies 3(1): 71-92. doi: 10.1023/A:1015630930326. 
Scherer, Stefanie and Nadia Steiber, 2007. 'Work and Family in Conflict? The Impact of Work Demands on Family Life.' In Gallie, Duncan, ed., Employment Regimes and the Quality of Work, pp. 137-178. Oxford and New York: Oxford University Press. doi: 10.1093/acprof:oso/9780199230105.003.0005.

Seligman, Martin E. P. and Mihaly Csikszentmihalyi, 2000. 'Positive Psychology. An Introduction.' American Psychologist 55(1): 5-14. doi: 10.1037/0003066X.55.1.5.

Sirgy, M. Joseph, 2002. The Psychology of Quality of Life. Dordrecht: Kluwer. doi: 10.1007/978-94-015-9904-7.

Szücs, Stefan, Sonja Drobnič, Laura den Dulk, and Roland Verwiebe, 2011. 'Quality of Life and Satisfaction with the Work-Life Balance.' In BäckWiklund, Margareta, Tanja van der Lippe, Laura den Dulk, and Anneke Doorne-Huiskes, eds., Quality of Life and Work in Europe. Theory, Practice, and Policy, pp. 95-117. Houndsmills, Basingstoke: Palgrave Macmillan. doi: 10.1057/9780230299443_6.

Valcour, Monique, 2007. 'Work-Based Resources as Moderators of the Relationship between Work Hours and Satisfaction with Work-Family Balance.' Journal of Applied Psychology 92(6): 1512-1523. doi: 10.1037/00219010.92.6.1512.

van der Lippe, Tanja, Stefan Szücs, Sonja Drobnič, and Leila Billquist, 2011. 'Data and Methods.' In Bäck-Wiklund, Margareta, Tanja van der Lippe, Laura den Dulk, and Anneke Doorne-Huiskes, eds., Quality of Life and Work in Europe. Theory, Practice, and Policy, pp. 55-74. Houndsmills, Basingstoke: Palgrave Macmillan. doi: 10.1057/9780230299443_4.

van Praag, Bernard M. S., Paul Frijters, and Ada Ferrer-i Carbonell, 2003. 'The Anatomy of Subjective Wellbeing.' Journal of Economic Behavior and Organization 51(1): 29-49. doi: 10.1016/S0167-2681(02)00140-3.

Voydanoff, Patricia, 2005. 'Toward a Conceptualization of Perceived Work-Family Fit and Balance. A Demands and Resources Approach.' Journal of Marriage and Family 67(4): 822-836. doi: 10.1111/j.17413737.2005.00178.x.

Weinberg, Ashley and Cary L. Cooper, 2007. Surviving the Workplace. A Guide to Emotional Well-being. London: Thomson. 